\title{
COMPARATIVE LAW AND THE IUS GENTIUM
}

\author{
Se-shauna Wheatle
}

\begin{abstract}
Constitutional principles are sometimes invoked in adjudication as a bridge to foreign law. This article argues that a cosmopolitan approach, such as that advocated by Jeremy Waldron through his ius gentium theory, is useful in accounting for the use of constitutional principles by courts insofar as the commonality of language and methodology surrounding the use of constitutional principles is connected to societal and institutional needs. The article argues that constitutional principles often serve as a connection to foreign law because the principles are applied as representations of a societal need for order and stability. At the same time, the article cautions that transnational judicial dialogue is impacted by compartmentalisation and divergence. Consequently, arguments for a ius gentium must be more cautious and nuanced. As a step in this direction, the article proposes two ideas for modifying the ius gentium theory: conceiving of the ius gentium as an emerging but not yet fully realised system and characterising the ius gentium as a convergence of methodology rather than substantive norms.
\end{abstract}

\section{The Concept of the Ius Gentium}

Legal principles are often invoked in adjudication as a bridge to foreign law and occupy an important space in the discourse on the existence of cosmopolitan norms. Jeremy Waldron taps into cosmopolitan theory by arguing that the use of foreign law in adjudication is part of the expression of 'laws common to all mankind', identifying universal legal principles as part of this ius gentium. ${ }^{1}$ The principles that contribute to the ius gentium are those that 'emerge from consensus in the legal world', consensus that is largely indicated by 'convergent currents of foreign statutes, foreign constitutional provisions, and foreign precedents.' These principles are therefore identified by their characteristic of commonality or universality. ${ }^{3}$ Waldron draws on Gaius's idea that countries governed by laws 'use partly their own laws and partly laws common to all mankind to

\footnotetext{
Durham Law School, Research Associate in Public Law.

1 J Waldron, Partly Laws Common to All Mankind (2012).

2 Ibid, 3, 68 .

3 Ibid, 28.
}

Copyright $\odot$ the Author(s).

This work is licensed under a Creative Commons Attribution-NonCommercial-NoDerivs 3.0 License. 
govern themselves'4 and identifies the ius gentium as a body of positive law that particularly applies to relations between the individual and government and also sometimes to relations between private individuals. ${ }^{5}$ Thus, as a substantive matter, the concept of ius gentium has special relevance human rights and constitutional norms, and the use of constitutional and human rights principles. As a methodological matter, the ius gentium theory is developed largely from comparative engagement between state legal institutions, including courts.

The cosmopolitan viewpoint is indeed useful in accounting for the use of constitutional and human rights principles by courts insofar as the commonality of language and methodology surrounding the use of such principles is connected to elemental social and institutional instincts. This article notes that there are common threads that permeate transnational judicial use of constitutional principles, particularly a theme of order and stability. However, a broader analysis of transnational judicial engagement presents a picture which is more nuanced than that presented by Waldron. This analysis is critical in light of the significant role played by judicial references to foreign law in the identification of the ius gentium. Judicial citations of foreign law are not only crucial to understanding the development of the ius gentium, they are also central to Waldron's motivation for expounding the ius gentium theory. The theory is used to justify and defend judicial references to foreign law. It seeks to accomplish this justificatory goal by maintaining that as lawyers, we are engaged in a common legal enterprise and are seeking to apply common principles to local settings, and that in looking to foreign laws, judges learn more about the application of those common principles. It becomes crucial then to interrogate the extent of commonality of the enterprise.

This article maintains that we must pay sufficient regard to the influence of historical and cultural divisions that compartmentalise the jurisdictions engaged in transnational judicial dialogue. This compartmentalisation and the divergence that results from it require that arguments for the ius gentium be more cautious and nuanced. Two alternative proposals are therefore advanced for adding more complexity to the ius gentium theory. The first proposal is that a ius gentium is emerging but it is not a current reality. The second is that to the extent that a ius gentium does exist, it is more accurately characterised as a convergence of methodology rather than one of substantive norms.

\footnotetext{
${ }^{4}$ Ibid, 3-4.

${ }^{5}$ Ibid, 28.
} 


\section{Principles that Travel Well}

The central defining characteristic of principles is that they are norms which may be applied with varying degrees of weight. ${ }^{6}$ It is partly this flexibility that permits principles to function as tools of transnational legal analysis. In particular, principles often serve as a connection to foreign law when they are applied as representative of a basic societal need for order. When used in this way, the principles 'travel well', to borrow an analogy employed by William Twining. The notion of travelling well speaks to the transferability of a concept across different jurisdictional, cultural and other contexts. In this sense, principles that are evoked as expressions of basic needs or inclinations are perfect candidates for norms that have achieved consensus in the legal world. The concept of principles that travel well is supported by way of illustration by cases that raise questions regarding the validity of legislation passed and institutions constituted in a manner and form that contradict the formal requirements of the Constitution. This is the scenario presented by cases that I will refer to as 'legal vacuum' cases-cases in which there is a serious threat of a substantial gap in the normative order of a jurisdiction. The designation 'legal vacuum' is not meant to be descriptive of the circumstances actually in existence at the time of the case. Rather, the term is applied here to refer to the spectre of such a vacuum arising depending on the legal and constitutional response to the lack of constitutional conformity. This includes post-revolution circumstances which arose in Grenada and Fiji, and the interesting case of the failure by the Canadian province of Manitoba to obey constitutional requirements for the bilingual publication of laws.

Legal vacuum cases represent an understanding of principles such as the rule of law and necessity that extend beyond local and cultural boundaries. Such cases not only use principles that have been accepted throughout constitutional democracies, they also reflect elemental social, institutional, and state inclinations towards order and stability. Those inclinations are so basic, particularly in legal vacuum cases, that they would generate broad-scale support across jurisdictions. In fact, there is an interesting connection between the legal vacuum cases and Waldron's defence of the use of foreign law: the idea of moral necessity. Waldron's argument is that if we suppose that there is something useful to learn from foreign law, particularly about basic rights, then it is a necessity to consult such foreign material in order to arrive at more intelligent and accurate

\footnotetext{
${ }^{6}$ R Dworkin, Taking Rights Seriously (1977) 26; R Alexy, A Theory of Constitutional Rights (J Rivers, tr; 2002) 48-57; Waldron, above n 1, 64.
} 
decision-making about rights. The consultation of foreign law, in this sense, contributes to the accuracy and fairness of the decision-making exercise. ${ }^{7}$ This moral necessity 'does not evaporate with the absence of a democratic basis for giving weight to foreign precedents or ius gentium principles. ${ }^{8}$ In a similar sense, in emergencies (circumstances in which there is an urgent threat to the legal order), ${ }^{9}$ when it is necessary that a decision be made for the common good, and there is no opportunity to use the proper democratic procedures, the decision can nonetheless be defended on the grounds of the moral necessity of the circumstances.

There is evidence of cross-jurisdictional consensus on the necessity of the stability and continuity of the legal order in cases from jurisdictions as diverse as Fiji, Canada and Grenada. This elemental need for order has long been recognised through constitutional provision for the exercise of executive and legislative powers during times of emergency and in justifications for extraordinary state action taken in exceptional situations. Thus, John Ferejohn and Pascale Pasquino maintain that emergency powers 'have long been thought to be a vital and, perhaps, even an essential component of a liberal constitutional-that is, a rights-protecting - government. ${ }^{10}$ The aim of such power is 'fundamentally conservative'; it is to resolve the threat to the system 'in such a way that the legal/constitutional system is restored to its previous state.11 The necessity of providing for exceptional or emergency situations is well-acknowledged, despite disagreement about the ultimate factual resolutions of such situations. ${ }^{12}$

The well-known Reference re Manitoba Language Rights ${ }^{13}$ case decided by the Supreme Court of Canada is pivotal in this discussion, partly because the court made explicit the elemental needs identified in this article. Section 133 of the Constitution Act 1867 and s 23 of the Manitoba Act 1870 required that all the Records and Journals of the Houses of the Parliament of Canada and of the

7 T Bingham, Widening Horizons: The Influence of Comparative Law and International Law on Domestic Law (2010) 7-8.

8 Waldron, above n $1,154$.

9 J Ferejohn \& P Pasquino, 'The Law of the Exception: A Typology of Emergency Powers' (2004) 2 IJ Con L 210, 210.

${ }^{10}$ Ibid, 211.

${ }^{11}$ Ibid, 210.

${ }^{12}$ For a recent proposal on the best responses to emergency situations, see D Dyzenhaus, The Constitution of Law: Legality in a Time of Emergency (2006).

${ }^{13}$ Reference re Language Rights Under s. 23 of Manitoba Act, 1870 and s. 133 of Constitution Act, 1867 (Manitoba Language Rights Reference or Reference re Manitoba Language Rights) [1985] 1 SCR 721. (Reference re Manitoba Language Rights) 
Legislatures of Quebec and Manitoba, and the Acts of the Parliament of Canada and of the Legislatures of Quebec and Manitoba, be printed and published in both English and French. The Manitoba Act 1870 is entrenched as part of the Constitution of Canada by virtue of s 52(2)(b) of the Constitution Act 1982. Yet, in 1890, the Manitoba Legislature enacted the Official Language Act 1890 (Manitoba), providing that Manitoba statutes need only be enacted and published in English. Subsequently, Manitoba ceased publication of French versions of its records, journals and legislation. In an effort to seek a comprehensive ruling on the legal status of English-only laws, the federal government sent a reference to the Supreme Court of Canada, asking the Court to determine, inter alia, whether the language requirements of s 133 of the Constitution Act 1867 and s 23 of the Manitoba Act 1870 were mandatory, and if so, whether Manitoba legislation that were not printed and published in both English and French were invalid by reason of s 23 of the Manitoba Act 1870. The court answered both questions in the affirmative, but on the second question, it clarified that 'the invalid current Acts of the Legislature will be deemed temporarily valid for the minimum period necessary for their translation, re-enactment, printing and publication. ${ }^{14}$ Thus, despite the clear unconstitutionality, the court nonetheless declared that the laws should be observed as temporarily valid in order to avoid a legal vacuum in the province.

The continuity of positive law was at the heart of the decision of the Canadian Supreme Court in the Manitoba case. This was reflected in the Court's assertion that the presence of the rule of law as a 'fundamental postulate' of the Constitution meant that the court had a ground on which to base its decision to declare the temporary validity of the Manitoba legislation. ${ }^{15}$ As the court put it, " $t$ ] he rule of law requires the creation and maintenance of an actual order of positive laws to govern society.' ${ }^{\prime}$ The maintenance of the positive legal order was perceived as essential to 'avoiding a legal vacuum in Manitoba and ensuring the continuity of the rule of law.'. Consequently, a 'declaration that the laws of Manitoba are invalid and of no legal force or effect would deprive Manitoba of its legal order and cause a transgression of the rule of law. ${ }^{18}$ This led to the conclusion that 'otherwise invalid acts may be recognised as temporarily valid in order to preserve

\footnotetext{
14 Ibid, para 157.

15 Ibid, para 63.

16 Ibid, para 60.

17 Ibid, para 67.

${ }^{18}$ Ibid, para 68.
} 
normative order and the rule of law, ${ }^{19}$

The nature of continuity which was discussed in this aspect of the judgment was quite elemental. It was recognition of the need for humans in any society to be governed by norms to guide behaviour and contribute to a system of social control. It is, in a word, elementary to the very existence and survival of the society. In societies governed by law, legal norms are particularly essential in maintaining social control and an ordered society. A state as a legal community cannot exist or survive without the existence of laws to condition inter-individual relationships and the relationships between the individual and the state. ${ }^{20}$ This sentiment was made explicit in the Manitoba case, the Canadian Supreme Court stating that the rule of law recognises that 'law and order are indispensable elements of civilised life.21 The elemental nature of the concern for securing normative order through the rule of law placed the issue faced by the court in a global context and indicated that the issue was not restricted to a provincial or national perspective. This globalized perspective was reflected in the Supreme Court's references to judicial decisions in Cyprus and Pakistan on the validity of unconstitutional statutes. In those foreign judgments, the courts invoked the doctrine of state necessity to validate otherwise unconstitutional legislation. The Canadian Supreme Court approvingly commented that ' $\mathrm{t}]$ he cases on the necessity doctrine [...] point to the same conclusion: the courts will recognise unconstitutional enactments as valid where a failure to do so would lead to legal chaos and thus violate the constitutional requirement of the rule of law. ${ }^{22}$ Since the preservation of a legal order would be essential to the survival of any state, this internationalised the issue in the Manitoba case and helped to justify the incorporation of foreign judicial decisions into the court's reasoning.

An internationalised issue is part of the crux of the response to 'localist' objectors to judicial comparativism in constitutional cases. The localist objection posits that constitutional adjudication in any jurisdiction must be grounded in the constitutional culture or constitutional identity of the nation in question. ${ }^{23}$ The argument is that the national locale is central to the interpretation of the requirements of the constitution and foreign law is accordingly irrelevant. If an issue can be construed as a global issue, the argument from constitutional locale

\footnotetext{
${ }^{19}$ Ibid, para 103.

${ }^{20} \mathrm{H}$ Kelsen, 'Law, State and Justice in the Pure Theory of Law' (1947-1948) 57 Yale LJ 377, 380.

${ }^{21}$ Reference re Manitoba Language Rights, para 64.

${ }^{22}$ Ibid, para 104.

${ }^{23}$ C Saunders, 'The Use and Misuse of Comparative Constitutional Law' (2006) 13 Ind J Glob Leg Stud 37.
} 
recedes in importance. However, in legal vacuum cases where the preservation of normative order becomes a central factor, the issue extends beyond local boundaries, the localist objection loses force and there is a stronger case for the relevance of foreign law.

The necessity of preserving law and order, which was at the basis of the Manitoba decision, has influenced judges in post-revolution jurisdictions to rely on similar legal principles and to engage in reasoning similar to that employed by the Supreme Court in Manitoba Language Rights. Such was the case in Mitchell v $D P P$, the facts of which it is useful to set out in some detail. The circumstances of the Mitchell case arose in the aftermath of a revolution in Grenada, a usually peaceful 'small island in the Eastern Caribbean.' ${ }^{24}$ A coup d'état was staged in March 1979 by the New Jewel Movement, the opposition party to the then ruling Grenada United Labour Party. The 'bloodless revolution' led to the establishment of the People's Revolutionary Government $(P R G)$ in 1979, led by Maurice Bishop, who assumed the position of Prime Minister of Grenada. The PRG suspended the Constitution of Grenada in 1973 and promulgated a set of People's Laws; the existing local courts were abolished as were appeals to the Judicial Committee of the Privy Council. A new Supreme Court consisting of a High Court and a Court of Appeal was created by People's Laws Nos 4 and 14. The PRG was overthrown in October 1983, when Maurice Bishop and some of his Ministers were murdered. Following the murders, a Revolutionary Military Council assumed power, which lasted for approximately one week, whereupon their reign was terminated when the island was invaded by forces from the United States of America, along with forces from some Caribbean states. The Governor General of the country then issued a proclamation declaring a state of emergency and declaring that he would exercise executive authority until a government was elected pursuant to the Constitution. The declaration also stated that 'existing laws' (including People's Laws Nos 4, 14, and 84, which established the new judicial system) would continue in force. Constitutional government returned when the Constitution of Grenada Order 1984 was published, which provided that the Constitution of 1973 was in force with the exception of some specified provisions, and a new Parliament was elected in December of 1984. The first Act passed by this new parliament in 1985 confirmed the validity of the laws passed during the PRG rule when the Constitution had been suspended.

The appellants in the case were charged with the murders of Maurice Bishop and other ministers of the PRG and were awaiting trial in the High Court. The

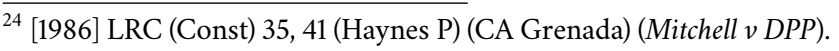


indictment against them was filed in September 1984, before the resumption of government under the Constitution. They applied to the High Court challenging the High Court's competence to hear the charge, on the ground that the court was established by the PRG under People's Laws Nos 4 and 14 and that since that government was invalid, those laws were invalid and hence the High Court itself as it was then constituted was invalid. Nedd CJ, sitting on the bench of the High Court, dismissed the application, holding that while the PRG was not the de jure government, the laws passed by it validly established the Supreme Court. ${ }^{25}$ The appellants then appealed to the Court of Appeal of Grenada. The issues raised on appeal included whether the PRG was the de facto government of Grenada, whether the PRG achieved de jure status before it was overthrown, whether People's Laws Nos 4 and 14 were valid, and whether the court had jurisdiction to hear the appeal before it.

The majority of the Court of Appeal held that there was insufficient evidence before it to decide whether the PRG had achieved de jure status. However, the court also held that People's Laws Nos 4 and 14 were validated under the law of necessity, and therefore the Supreme Court (including the Court of Appeal itself) was validly constituted. ${ }^{26}$ Haynes $\mathrm{P}$ indicated that one of the maxims from which the doctrine of necessity is derived is that stated by Bacon: 'that the preservation of the state is the supreme law (salus populi suprema lex), ${ }^{27}$ Based on this understanding, the President of the Court of Appeal listed five conditions for the operation of the doctrine of necessity, the first among these being that an imperative necessity must arise because of the existence of exceptional circumstances not provided for in the Constitution, for immediate action to be taken to protect or preserve some vital function of the State. Simeon McIntosh, a respected Caribbean legal academic, criticised the Court's application of the doctrine of necessity to the case on the basis that the circumstances before the court did not constitute an 'emergency' within the meaning required by the necessity doctrine because the doctrine only applies to unconstitutional acts performed by a constitutional state. ${ }^{28} \mathrm{He}$ also based his criticism on the argument that it is only a court that is itself already validly constituted that would have jurisdiction' in the case. ${ }^{29}$ McIntosh's latter criticism-regarding the validity of

\footnotetext{
${ }^{25}$ The Chief Justice's decision was given ten days after the Constitution of Grenada Order 1984, which reinstated the Constitution of 1973.

${ }^{26}$ Mitchell v DPP, paras 73-4, 88-94, 120.

${ }^{27}$ Ibid, para 76.

${ }^{28}$ S McIntosh, Kelsen in the Grenada Court: Essays on Revolutionary Legality (2008) 28.

${ }^{29}$ Ibid, 37.
} 
the court-certainly indicates a logical flaw in the decision. However, a court before which this issue is raised must decide; that is a critical distinction between judicial practice and legal theory. As the Court recognised, it was imperative for it to give a reasoned decision that would provide guidance and certainty in the face of disorder.

The commonality of concern for maintenance of law and order was again on display in the use of the doctrine of necessity in successive cases in Fiji, in which the courts referred to the Mitchell judgment and adopted most of the conditions of the necessity test enumerated by the Grenadian Court of Appeal. ${ }^{30}$ The Parliament of Fiji was subject to an armed invasion and coup in May 2000, the Prime Minister and other ministers being taken hostage. The President declared a state of emergency, appointed a free minister to act as Prime Minister, and under s 59(2) of the Constitution, prorogued Parliament for six (6) months. The acting Prime Minister then resigned. The military commander assumed executive authority as head of an interim military government, made decrees suspending parts of the Constitution and decrees that holders of constitutional offices and organs of government, including courts (other than the Supreme Court) should continue to operate. He installed an interim civilian government and an interim President without first consulting the Prime Minister (who had by that time been released), in accordance with s 90 of the Constitution. The applicant, a farmer who claimed to have lost rights by the suspension of his constitutional rights, issued an originating summons in the High Court, seeking a ruling that the 1997 Constitution was still in force as the supreme law. Gates $\mathrm{J}$ in the High Court held that the declaration of a state of emergency was valid under the doctrine of necessity, but that necessity could not be invoked to justify a purported abrogation of the Constitution by the establishment of a new extra-constitutional regime. Therefore, the interim civilian government was not legally established and the Constitution of 1997 remained in force, with the result that the applicant's claim succeeded on most points. The Court of Appeal dismissed the government's appeal-employing different reasoning to arrive at the conclusion that the interim civilian government was invalid-but upheld the legality of many of the military commander's acts under the doctrine of necessity. Again, as in the Grenadian and Canadian cases, the primary concern was with what actions and steps were necessary for the 'ordinary orderly running of the

\footnotetext{
${ }^{30}$ Prasad v Republic of Fiji [2001] 2 LRC 743 (Fiji CA) (Prasad v Fiji); Qarase v Bainimarama [2008] FJHC 241. See M Head, 'The Doctrines of Necessity and Revolution: A Critical Review of Republic of Fiji Islands and Attorney General v Prasad' (2001) Australian ILJ 259; N W Barber, 'State Necessity and Revolutionary Legality in Fiji' (2001) 117 LQR 408.
} 
State. ${ }^{31}$ Despite the distinction between the results of Mitchell and Prasad, there was a common motivating factor of preventing anarchy. In fact, though the Court of Appeal in Prasad held that the Constitution remained the valid supreme law, its ruling ensured that there was no legal vacuum by upholding the legality of many acts of the military commander and by permitting the Acting President, who had been appointed by the military, to remain in office for a limited period. Again, therefore, the court's decision ensured the maintenance of law and order, despite the violation of the formal requirements of the Constitution.

In all of these cases, the reader may also have noticed strong institutional undertones. One aspect of the institutional implications relates to the institutional legitimacy of the court in ruling on the issues before it. However, the primary institutional concern is that of the preservation of the validity of essential state organs. This was central to the Mitchell case, where the validity of the court itself was being challenged, prompting Peterkin JA to refer to 'the impossible situation which could and would arise without the presence of a Court in Grenada., ${ }^{32}$ Likewise, in explaining why it was necessary to deem that the Acts of the Legislature of Manitoba were temporarily valid, one of the concerns highlighted by the Canadian Supreme Court was that of the legitimacy of the institutions of the province. In holding that the rule of law demanded the declaration of temporary validity, the court summarised the potential impact on the institutions of government in the province of Manitoba if the Acts of the province were invalidated with immediate effect:

The situation of the various institutions of provincial government would be as follows: the courts, administrative tribunals, public officials, municipal corporations, school boards, professional governing bodies, and all other bodies created by law, to the extent that they derive their existence from or purport to exercise powers conferred by Manitoba laws enacted since 1890 in English only, would be acting without legal authority. ${ }^{33}$

The validity of the Legislative Assembly of Manitoba would itself have been open to doubt if the court had not proceeded to grant temporary validity to the English only laws. While the Manitoba Legislature was validly established by the Manitoba Act 1870, subsequent to 1890, English only laws had been

\footnotetext{
${ }^{31}$ Prasad v Fiji, 774, quoting Madzimbamuto v Lardner-Burke [1968] 3 All ER 561, 579 (Lord Pearce).

${ }^{32}$ Mitchell $v$ DPP, para 121 (Peterkin JA).

${ }^{33}$ Reference re Manitoba Language Rights, para 56.
} 
passed relating to the franchise and the composition of the Legislature. This raised the prospect that not only would a legal vacuum exist, but the Legislature would lack the institutional legality to fill this vacuum. ${ }^{34}$ For these institutional reasons, along with the potential impact on the substantive law of the rights and obligations arising under unilingual Acts passed after 1890, the court concluded that 'declaring the Acts of the Legislature of Manitoba invalid and of no force or effect would, without more, undermine the principle of the rule of law'. Hence, the Court invoked the rule of law not merely to preserve the authority of the positive laws, but also to ensure the maintenance of institutional authority to generate and implement the laws of the state.

The constitutional principles called upon by the courts in these cases (necessity and the rule of law) fit neatly into the notion of cosmopolitan norms because these principles, as used in the cases above, are concepts that provide a direct link to basic societal needs. Thus, they are principles and concepts that 'travel well' because they are so intimately connected to the elemental needs of society. ${ }^{35}$ What the courts responded to in the cases discussed above was not simply analysis of national laws and national circumstances; they responded to universally recognised necessities. Thus, whatever the disputes among academics and judges about the exact contours of the doctrine of necessity, it is generally agreed that it renders lawful or valid acts which are 'necessary to peace and good order. ${ }^{36}$ Similarly, despite the ongoing and complex debates regarding the content of the rule of law, it is universally accepted that it requires, at a minimum, the existence of laws. ${ }^{37}$ This element of universality in turn facilitates and justifies references to foreign law. From this perspective, we do see principles functioning in a way that suggests there is some merit in Waldron's ius gentium analysis. However, as discussed below, there is much more to the use of constitutional and human rights principles, some of which would not be classified as principles that travel well. Further, there are other inter-jurisdictional dynamics that must inform our analysis in order to give a more accurate account of the implications of transnational judicial discourse.

\footnotetext{
${ }^{34}$ P Hogg, 'Necessity in a Constitutional Crisis' (1989) 15 Mon LR 253, 255.

${ }^{35}$ See W Twining, 'Have Concepts, Will Travel: Analytical Jurisprudence In a Global Context' (2005) 1 Int'l J L Con 5.

${ }^{36}$ Texas $v$ White (1868) 74 U.S. (7 Wallace) 700, 733; Head, above n 28, 268.

${ }^{37}$ P Craig, 'Formal and Substantive Conceptions of the Rule of Law: An Analytical Framework' [1997] PL 467; A L Young, 'The Rule of Law in the United Kingdom: Formal or Substantive?' (2012) 6 Vienna J Int'l Const L 259; T Bingham, The Rule of Law (2010).
} 


\section{Legal Decision-Making?}

The use of principles in legal vacuum cases appear to be attempts to identify and glean the core elements of the state and the constitution by 'dig[ging] down to the level of constitutional theory ${ }^{38}$ to apply the core of foundational principles of the constitution. So, for instance, if in a case such as Reference re Manitoba Language Rights, a principle is used to ensure the maintenance of laws in a jurisdiction, this is a core application of the rule of law, universally accepted, that the rule of law requires that there must exist a positive order of laws. So while there may be controversy surrounding the court's resolution of the facts of the case, it is unlikely that there would be debate surrounding the court's statement that the rule of law demands that there must be laws. Similarly, despite its potential for substantial effect on the legal, political, and social structures of the state, the doctrine of necessity has generally been recognised as one of ancient vintage and, in fact, was relied upon by an English court as early as $1672 .{ }^{39}$ Indeed, Glanville Williams identified twelve maxims justifying the doctrine of necessity ${ }^{40}$ and he justified its place in the law, noting that:

'The law' is not a body of systematised rules enacted as a whole and fixed for all time. Judges have always exercised the power of developing the law, and this is now recognised to be a proper part of their function. 'The law', in a word, includes the doctrine of necessity; the defence of necessity is an implied exception to particular rules of law. ${ }^{41}$

With respect to the Grenadian Court of Appeal's judgment in Mitchell, though McIntosh criticised the court's ruling, his critique was based on his view that the Court 'misconstrued the doctrine' 42 and not on the ground that the doctrine itself was an illegitimate tool of judicial decision-making. Importantly, it has been noted by Mark Stavsky, commenting on the use of the doctrine of necessity in Pakistan, that '[i]f narrowly and carefully applied, the doctrine constitutes an affirmation of the rule of law. ${ }^{43}$ Indeed, the Supreme Court of Canada stated

${ }^{38} R v$ Secretary of State for the Home Department, ex parte Pierson [1998] AC 539, 584.

${ }^{39}$ Manby $v$ Scott (1672) 1 Lev 4. See also M Stavsky, 'The Doctrine of State Necessity in Pakistan' (1983) 16 Cornell ILJ 341, 342.

${ }^{40}$ G Williams, 'Defence of Necessity' (1953) 6 CLP 216.

${ }^{41}$ Ibid, 224.

${ }^{42}$ McIntosh, above n 28, 28.

${ }^{43}$ Stavsky, above n 39, 344. 
in the Manitoba case that 'the doctrine of necessity is not used in these cases to support some law which is above the Constitution; it is, instead, used to ensure the unwritten but inherent principle of rule of law which must provide the foundation of any constitution. 44

It is also crucial to acknowledge that in legal vacuum cases, the court plays a secondary role in ascribing validity to legislation under an understanding that it is 'necessary' to do so. The secondary role of the court is key to an assessment of the institutional legitimacy of the court's decision-making in such cases. ${ }^{45}$ Therefore, in these cases, the central factual circumstance is that the legislature and/or executive of the jurisdiction promulgated acts that would, in ordinary circumstances, be invalid; the primary legal actors are the elected branches of state. It is only subsequently that the court becomes involved, when asked to legally acknowledge the necessity of the exceptional acts and to confer partial (that is, temporary) or complete validity on the prior legislative or executive acts.

Despite the universally accepted necessity of providing for emergencies, there remain doctrinal and institutional difficulties regarding courts' approach to such circumstances. One persistent question provoked by the legal vacuum cases is whether the decision-making that occurs in such cases is actually appropriately denoted 'judging' or 'legal decision-making' or more accurately characterised as decisions primarily motivated by practicality or political (necessity). ${ }^{46}$

Considering the Manitoba case, while the court determined that the rule of law was an applicable principle in the case, the rule of law could have led the court in opposite directions. First, it could have been applied as a requirement that the court and other institutions obey the text of the Constitution, which prescribed that, in order to be valid, the laws enacted must be bilingual. The result of such an application of the rule of law would be the immediate nullity of the unilingual laws. A conflicting application of the rule of law-the one chosen by the court-was that the rule of law requires an order of positive laws. As shown above, the result of this application was the (temporary) validity of the laws. The question therefore arises of what factors resulted in the court's choice of the latter application of the rule of law. It is certainly plausible to propose that the choice between the two applications of the rule of law was motivated by political or practical considerations that are outside the scope of legal norms. A decision-making process that takes into account such considerations challenges

\footnotetext{
${ }^{44}$ Reference re Manitoba Language Rights Reference, para 105.

${ }^{45}$ Cf Hogg, above n 34, 262, 263.

${ }^{46}$ Head, above n 30, 259-60.
} 
the legitimacy of the court's judgment as a legal judgment.

\section{Divergence and Dilution}

Despite the common threads of transnational law that unite the legal vacuum cases, empirical and critical analysis of a wider array of judicial decisions also demonstrate that the influence of history creates regional and national distinctions that must be taken into account. While some underlying instincts may be common to the point of being universal, the transnational judicial development of principles diverge along fault lines influenced by history, institutional development, and pedagogical and educational patterns.

\subsection{Methodology}

Thus, while there is an underlying strain of cosmopolitanism, it is limited by historical, institutional and doctrinal factors that must be appreciated in our understanding of the methodology and implications of the judicial use of principles. Thus, unsurprisingly, discourse occurs heavily within constitutional networks, which share a common language and/or a common legal heritage. ${ }^{47}$ This does not mean there is no exchange between networks, but it does mean that there is much more discourse and legal exchange on the intra-network level than the inter-network level, and this must affect the content and application of the principles recognised by respective judicial institutions.

A further nuance that must influence our analysis is the dimension of discursive power which not only contributes to the existence of regional and sub-regional pockets of transnational discourse, but also significantly affects the content of norms and the relative normative influence of jurisdictions. We must squarely confront the questions whether if there are laws common to all mankind, who plays a role in determining the content of these laws, and what is the extent of the role played by different countries? While Waldron cautions us not to make the mistake of thinking the issue is 'global uniformity', he nonetheless posits that ' $[\mathrm{t}$ ] $\mathrm{o}$ a large extent, we treat law more like a science-as a global enterprise of which we partake-than like a national costume or some aspect of the culture we would put on show to establish our distinctiveness. ${ }^{\text {,4 }}$ The central notion of

\footnotetext{
${ }^{47}$ D Law \& M Versteeg, ‘The Evolution and Ideology of Global Constitutionalism' (2011) 99 Cal LR 1163; W Chang \& J Yeh, 'Internationalization of Constitutional Law' in M Rosenfeld \& A Sajó (eds), The Oxford Handbook of Comparative Constitutional Law (2012) 1165, 1173-6.

${ }^{48}$ Waldron, above n 1, 5 (emphasis added).
} 
a 'global enterprise of which we partake' must be interrogated by examination of the evidence provided by actual judicial citations in the context of history and geopolitical dynamics. Acknowledging that a substantial avenue through which we partake in the exercise of the law is through judicial reasoning and decision-making, and that judicial references to foreign law play a significant role in the ius gentium theory, we must take account of the imbalances in the transjudicial discourse. The imbalances are evidenced by empirical data.

Empirical evidence of citations of foreign precedent by the Australian High Court between 2000 and 2008, shows that UK and US authorities account for over 80 percent of citations, with Canada being the third most frequently cited and New Zealand the fourth. ${ }^{49}$ Canada tells a similar tale, with the USA and the UK comprising over 88 percent of the citations to foreign precedents in constitutional cases decided by the Supreme Court of Canada between 1982 and 2010. Australia and the European Court of Human Rights earned third and fourth places, respectively. ${ }^{50}$ Part of accounting for these figures is that there is a tendency to cite jurisdictions that are former members of the British Empire, share a common law tradition or speak a common language. Thus, this is partly a function of the fact that judicial dialogue tends to occur within regions and within the same legal (and linguistic) family. The legal family ties are particularly heightened in the common law. ${ }^{51}$ There is a perception of the common law as a unified whole, which is reflected in judges speaking to the desirability of convergence and even unity within the common law, particularly within regional groups of common law jurisdictions. Lord Bridge stated in Bennett $v$ Horseferry Road Magistrates' Court:

Whatever differences there may be between the legal systems of South Africa, the United States, New Zealand and this country, many of the basic principles to which they seek to give effect stem from common roots. ${ }^{52}$

\footnotetext{
${ }^{49}$ C Saunders \& A Stone, 'Reference to Foreign Precedents by the Australian High Court: A Matter of Method' in T Groppi \& M Ponthoreau (eds), The Use of Foreign Precedents by Constitutional Judges (2013) 13, 33-4.

${ }^{50}$ G Gentili, 'Canada: Protecting Rights in a "Worldwide Rights Culture", An Empirical Study of the Use of Foreign Precedents by the Supreme Court of Canada (1982-2010)' in T Groppi and M Ponthoreau (eds), The Use of Foreign Precedents by Constitutional Judges (2013) 39, 57-9.

${ }^{51}$ E Örücü, 'Comparative Law in British Courts', in U Drobnig \& S van Erp (eds), The Use of Comparative Law by Courts (1999).

${ }^{52}$ [1994] 1 AC 42, 66 (HL).
} 
The Judicial Committee of the Privy Council has also encouraged regional unity within common law jurisdictions, stating approvingly in an appeal from the Caribbean state of Belize that the Judicial Committee's decision 'will bring Belize into line with other Commonwealth countries of the Caribbean. ${ }^{\text {, }}$

Waldron does acknowledge the legal family critique of claims of a legal consensus and universalism, but issues the rejoinder that a 'self-referential starting point does not preclude the possibility of projection unto an unfamiliar environment'. He encourages us to accept that ius gentium is still valuable despite that it develops unevenly, 'in fits and starts'. The difficulty that remains, even accepting this encouragement, is that as compartmentalised as the discourse is, it is more accurate to perceive ius gentium as emerging but not truly existing as a current system. There is as yet no global system and it is more accurate to see a global system as a possibility in the future but not a reality at present.

A further level of scrutiny that should be undertaken is to account for the fact that even within legal families, there are imbalances in transnational citations. Within the common law system, some former members of the British Empire are referenced with remarkably higher frequency than others. During the period 1982-2010, the Canadian Supreme Court made only five references to Indian case law and 4 to Caribbean case law, compared with 81 references to Australian and 32 to New Zealand case law. ${ }^{54}$ In the Australian High Court, from 2008-2008, there were no references to the Commonwealth Caribbean and only 15 Indian references compared with 317 for Canada and even 36 for the European Court of Human Rights. ${ }^{55}$ The limited reciprocity in cross-referencing between jurisdictions also undermines claims that there is true transnational dialogue. For example, it has been observed that while the Canadian Supreme Court and the South African Constitutional Court cite each other, the latter cites the former approximately three hundred times more often than vice versa. ${ }^{56}$

There are several practical factors that likely contribute to these imbalances. One of the more apparent factors is the relative volume of case law generated by comparator jurisdictions; for instance, the Supreme Court of Canada produces more constitutional and human rights rulings, in terms of sheer numbers, than for instance, the Caribbean Court of Justice. But that cannot be the sole explanation when we consider that the Indian Supreme Court, for instance, also generates a

\footnotetext{
${ }^{53}$ Vasquez v R [1994] 1 WLR 1304, 1314 (PC).

${ }^{54}$ Gentili, above n 48.

${ }^{55}$ Saunders \& Stone, above $\mathrm{n} 47$.

${ }^{56}$ Chang \& Yeh, above n 45, 1176.
} 
high volume of case law, ${ }^{57}$ yet the Indian Supreme Court is cited with much less frequency than the Canadian Supreme Court. A further practical consideration is that of 'documentary access' to case law emanating from some jurisdictions. Other practical factors include institutional affiliation with educational facilities in the more developed states ${ }^{58}$ and functional resource-based considerations that encourage states to consult the judicial record of jurisdictions that have already addressed difficult issues in hard cases.

Beyond practical considerations, there are broader influence-based factors such as the fact that there may be more pedagogical value in referring to judgments of older democracies, and the perception that some jurisdictions are more 'developed' and therefore have greater reputational currency. Accordingly, some of the power imbalance is a function of relative global influence that extends beyond law, and is reminiscent of geopolitical imbalances that occur in normative legal systems that involve the interaction of multiple jurisdictions in a global setting. ${ }^{59}$ Thus, there is not only a problem of documentary access in relation to various jurisdictions, but also documentary influence.

There is some acknowledgment of the issue of reciprocity in citations by Waldron. He briefly discusses citations among Commonwealth jurisdictions, pointing to Commonwealth jurisdictions citing each other, but makes three analytical errors. First, in speaking of 'the Commonwealth', he falls into a familiar pattern of limiting the Commonwealth almost exclusively to Australia, New Zealand and Canada. Of course, the Commonwealth of Nations is a much broader, more diverse group, with a host of potentially constitutionally significant case law. It is true that sometimes there is less to be gained from referring to developing nations that have not confronted some of the problems facing more developed countries in fields such as commercial or contract law, ${ }^{60}$ but this does not account for or justify neglect of literature from developing countries on constitutional issues. Secondly, commenting on the citation by other Commonwealth countries of the United Kingdom, Waldron maintains that 'the citations go in both directions'. However, he does not adequately address

\footnotetext{
${ }^{57}$ See N Robinson, 'A Quantitative Analysis of the Indian Supreme Court's Workload' (2012) $10 \mathrm{~J}$ Emp Leg Stud 570.

${ }^{58}$ See references to the influence of intellectual tradition in Hinds $v$ [ [1977] AC 195, 212 (PC).

${ }^{59}$ See e.g. N Krisch, 'International Law In Times of Hegemony: Unequal Power and the Shaping of the International Legal Order' (2005) 16 EJIL 369; P Singh, 'From "Narcissistic" Positive International Law to "Universal" Natural International Law: The Dialectics of "Absentee Colonialism”" (2008) 16 Af JICL 56.

${ }^{60}$ Waldron, above $\mathrm{n} 1,200$.
} 
the critiques regarding the frequency of citations by the UK courts of other Commonwealth countries, and regarding which other Commonwealth countries are most frequently cited. In short, he does not sufficiently address the question of the extent of reciprocity in citations. Thirdly, Waldron does not raise the question whether a significant proportion of the citations by UK courts to other Commonwealth countries are actually references to the judgments of the Privy Council and therefore indicative of citations to a Bench that substantially overlaps with members of the UK House of Lords. ${ }^{61}$

The discussion regarding which jurisdictions are engaged in the dialogue and the extent and character of their engagement affects at least three issues. This discussion most clearly impacts the issue of who creates these norms (who are the norm-makers) because even if these norms are understood to arise in societies generally, if we assert that they are distinct from natural law, we must acknowledge the existence of norm-makers and engage in discourse identifying norm-makers and characterising their influence in the process of norm creation.

Second, the extent of engagement of jurisdictions also affects the content of the norms. We must accept some of the critiques of legal and cultural relativism, by acknowledging that the meaning of some norms and concepts are shaped by the legal and cultural space from which the norms emanate and to which they apply. ${ }^{62}$ Accordingly, the exclusion or marginalisation of particular states within transnational discourse means that the perspectives of their legal and social frameworks will also have little or no impact on the developing norms. Conversely, the frameworks of states that are actively engaged will be more heavily reflected in the norms identified in the cosmopolitan arena. The result is not that we should accept legal and cultural relativism wholeheartedly, but that we should seek to recognise some truth in relativist critiques of comparativism and cosmopolitanism.

This calls for heightened self-awareness on the part of those engaged in comparative analysis. From the postmodernist perspective, the comparative exercise is critiqued on the basis that comparatists (whether practitioners or academics) approach their work from their own cultural frameworks. Postmodernists maintain that the comparatist's cultural framework affects the epistemological choices, functional analysis and normative reasoning of comparative work. The impact of framework bias means that the dominant cultural framework is exalted in comparative studies and there is an iterative process of exclusion of 'the other' cul-

${ }^{61}$ See J Bell, 'Comparative Law in the Supreme Court 2010-11' (2012) 1 CJICL 20, 23.

${ }^{62}$ Singh, above n 59; Twining, above n 33. 
ture(s). This sort of critique is familiar and, indeed, understandable where multiple jurisdictions interact within a transnational or global setting. Thus, as international law has been assailed by complaints of eurocentricity and asymmetry between the global north and south, comparative law has been subjected to similar critique. ${ }^{63}$ Indeed, the empirical data presented above demonstrates that some of this critique is justifiable, as there is an imbalance in favour of the global north and west and marginalisation of the global south and east. The comparatist, must, in response, cultivate a high level of consciousness of her cultural influences, her methodological choices and the relationship between her research and the dominant political and cultural climate. ${ }^{64}$ In short, the comparatist must be self-aware and acknowledge her own cultural framework. To the extent that she advances claims of universalism while brushing aside concerns of hermetic and imbalanced engagement, she is signalling that for her, the 'legal world' is represented by those jurisdictions that fit within her own cultural framework.

This self-critical approach is all the more important where there are cosmopolitan or universalist goals within the comparatist's work. Such goals broaden the field of study and simply make it harder to achieve accurate conclusions, and a cosmopolitan or universalist outlook heightens the probability of dominance of the discourse by the prevailing cultural framework. The ius gentium theory, as presented by Waldron, fails to be sufficiently self-conscious and selfcritical. The current defence of the theory misses the opportunity to acknowledge, interrogate and account for the imbalances in comparative engagement.

Third, we should also question whether the engagement factor affects the objects of the norms, that is, to whom they should apply. If there is no equal engagement in the norm-making process, then arguably the norms are not accurately characterised as part of a ius gentium either in their creation or in their application. Now, it might be claimed by defenders of Waldron's theory that the ius gentium does not perceive jurisdictions as constituents; that individuals are the true constituents, and that the concerns regarding state engagement are misplaced or overblown. This rejoinder, is however, unconvincing. While individuals may be the constituents of a ius gentium, in the current framework it is state institutions that represent, speak for, and create norms for, individuals. Indeed, institutional context is a crucial element in constructing an account

\footnotetext{
${ }^{63} \mathrm{~J} \mathrm{~T}$ Gathii, 'International Law and Eurocentricity' (1998) 9 EJIL 184; A Gupta, 'Constitutional Pluralism, a Recent Trend in International Constitutional Law: European Origins and the Third World Concerns' (2011) 36 S Af YIL 37, 52.

${ }^{64}$ H Schwenke \& A Peters, 'Comparative Law Beyond Post-Modernism' (2000) 49 ICLQ 800, $829-30$.
} 
of transnational law, even a cosmopolitan account of transnational law. ${ }^{65}$ It is through legal and political institutions that individuals participate in the cosmopolitan space envisioned by the ius gentium theory.

These are all salient questions which ought to affect our assessment of whether nations are engaged in reciprocal or true dialogue. The imbalances discussed above undercut the commonality of the norms that would form part of the ius gentium and undermine the claim that the enterprise is truly global. To sustain the claim of the global enterprise and the ius gentium, these issues must be confronted in detail. Moreover, assuming the usefulness of citing foreign law, particularly as a technique to improve the accuracy and fairness of decision-making, imbalanced judicial discourse adversely affects the benefits of judicial comparativism as it diminishes the perspectives that inform judicial decision-making. If one function of comparativism is to enable courts to treat like cases alike, imbalanced engagement severely undermines this objective, as it distorts the pool of 'like cases'.

One proposal for addressing these issues is to acknowledge that while a ius gentium is in the process of development, it has not yet emerged as a fully fledged system of law. This proposal would address criticisms regarding the compartmentalised and imbalanced nature of current transnational judicial discourse. It is recognition of the reality that 'much of the transnationalisation of law and legal relations is taking place at sub-global levels'. ${ }^{66}$ This approach maintains the overall theme of moving beyond the state but is more realistic in its description of the current models of transnational dialogue. Moreover, describing ius gentium as emerging has the advantage of being more modest than Waldron's theory, but does not foreclose the possibility that the ius gentium as described by Waldron may one day exist. It admits of this possibility and even encourages it, by urging a more self-aware and culturally sensitive process of comparative reasoning and comparative scholarship.

\subsection{Principles}

A further issue relating to the usefulness of the ius gentium theory is the dilution of principles operating in a cosmopolitan space. Principles tend to be capable

\footnotetext{
${ }^{65}$ For instance, Vlad Perju's articulation of cosmopolitan dimensions of constitutional law is largely institutionalist: V Perju, 'Cosmopolitanism and Constitutional Self-Government' (2010) 8 IJ Con L 326, 328-30.

${ }^{66}$ W Twining, 'Globalisation and Comparative Law' in E Orücü \& D Nelken (eds) Comparative Law: A Handbook (2007) 69.
} 
of flexible application since they 'do not operate in an all-or-nothing fashion' and can be applied with varying degrees of weight. ${ }^{67}$ It is partly the level of generality of principles that makes them particularly attractive in comparative judicial exchanges. The universalistic nature of constitutional principles such as, for instance, the rule of law and separation of powers at a high level of abstraction means that their invocation does not, ipso facto, threaten the commitment to the particular values and local conditions of the state in question. However, courts use foreign citations relating to principles in a variety of ways, depending on the perspectives of the judges in the case, the textual arrangements of the constitution, and the social and political circumstances of the society. This may include a decision by the court to reject a particular understanding of the principle as articulated by another jurisdiction. For example, in $R v$ Kirby, ex parte Boilermakers' Society of Australia the Australian High Court referred to US law on the requisite separation of powers between state institutions, but indicated that the division in the Australian constitution 'is a division of powers whose character is determined according to traditional British conceptions. ${ }^{68}$ For the High Court, articulating this division 'according to traditional British conceptions' meant that, while the operation of the separation of powers principle in the US required separation of the executive and the legislature, in Australia 'difficulties as between executive and legislative power are not to be expected' ${ }^{69}$

The argument from abstraction and vagueness is a familiar critique of the articulation of principles as norms and the use of principles in judicial decision-making. ${ }^{70}$ Thus, for instance, Raz objects that '[p]rinciples, because they prescribe highly unspecific acts, tend to be vaguer and less certain than rules. $^{\text {,1 }}$ Larry Alexander is similarly unconvinced by the model of principled decision-making, arguing that legal principles combine the worst features of pure moral reasoning and decision-making by precedent rules. In Alexander's account, if legal principles are not moral principles, the court cannot disregard all past decisions that it deems morally wrong, as that would undermine the coherence within the legal system. Yet, despite these constraints, legal principles do not possess the 'compensating settlement value of decision-making according

\footnotetext{
${ }^{67}$ Dworkin, above $\mathrm{n}$ 6, 24, 35.

${ }^{68}$ (1956) 94 CLR 254, para 13

${ }^{69} \mathrm{Ibid}$.

${ }^{70} \mathrm{~J}$ Raz, 'Legal Principles and the Limits of Law' (1972) 81 Yale LJ 823; L Alexander, What are Principles, and Do They Exist? (San Diego Legal Studies Paper No 13-119, 2013) <http://ssrn.com/abstract $=2277787$ or http://dx.doi.org/10.2139/ssrn.2277787> [accessed 1 January 2015].

${ }^{71}$ Raz, above n 70, 841.
} 
to rules' because principles 'tend to be more vague and more dependent on value-laden terms than posited rules that prescribe results for future cases' and because the process by which competing principles should be weighed is elusive. $^{72}$

These critiques are heightened when the principles have to be diluted in order to be relevant in a cosmopolitan arena. When principles are proposed as part of the ius gentium, they exist at such a high level of abstraction that this raises the question whether it is accurate or meaningful to characterise them as norms. The point here might not be so much to reject these principles in toto; the rule of law, or a doctrine of necessity, or a requirement for separate or divided powers, for instance, have the capacity to be norms. The principles might exist as norms within national jurisdictional boundaries but when they are transposed to the cosmopolitan level, they become so general that they lose the quality of norms. It is crucial to the ius gentium theory that the body of principles that connect the nations of the world are not natural law, but global legal norms. The difficulty is that the attempt to present these principles as global or universal makes them particularly vulnerable to the critique that they are nothing more than expressions of morality or expressions of natural law. ${ }^{73}$

A proposal for responding to the generality problem is that we should redirect our focus from trying to identify these principles as part of a ius gentium and instead identify cosmopolitan methodologies for legal decision-making. This reframing would address the critique regarding the dilution of the principles as norms. It would engage with the ongoing conversation about convergences in techniques of decision-making, such as discourse about the expansion of the use of concepts such as proportionality, the growth in citations of foreign law and the use of principles in arguments and legal reasoning. Such trends in decision-making techniques traverse many borders and they lead to a more modest claim regarding the similarities in devices and frameworks for legal decision-making, rather than a claim regarding the content of substantive norms. It changes the conversation from one about content of principles to the role that principles and other decisional devices play in judicial decision-making.

\footnotetext{
${ }^{72}$ L Alexander \& E Sherwin, 'Judges as Rule Makers' in D E Edlin (ed), Common Law Theory (2007) $27,44-5$.

${ }^{73}$ See, regarding principles as nothing more than moral principles, Alexander, above $\mathrm{n} 70$.
} 


\section{Conclusion}

The concept of need is a central aspect of the above discussion of the cosmopolitan account of the transnational judicial use of constitutional principles. Societies need order, and in the aftermath of revolutions or other departures from regular democratic constitutional processes, there remains a need for laws to forestall a legal vacuum. Need also plays a role in the explanation of the proliferation of norms that transcend national boundaries. One commentator notes that as we engage in more trade, transactions and communications across national and continental boundaries, 'we have more need for law that transcends national and cultural borders along with us. And as the great challenges of our age [...] have become global, we are forced to become global ourselves and develop a legal framework that allows us to address these problems in an adequate way. ${ }^{74}$ Thus, there is a need for global law, conceptualised as a 'point of convergence' for legal systems. It is partly this need that cosmopolitanism in general and Waldron's thesis regarding the ius gentium, in particular, seek to satisfy. However, this article has sought to show that while there is some convergence on central, core applications of constitutional principles relating to basic needs, there are complexities arising from history, legal traditions and geopolitical dynamics that affect the process of transnational engagement, and the content of the principles that form part of the ius gentium.

What emerges is that advancing a theory of ius gentium using (constitutional and human rights) principles runs the risk of magnifying the Achilles' heels of both comparative law and reasoning by principles. With respect to reasoning by principles, the ius gentium theory may serve to further highlight the abstract and vague nature of principles, fuelling the fire of sceptics who doubt the normative value of legal principles. The comparative enterprise is made more vulnerable to the post-modernist critique that comparatists pursue an 'agenda of sameness' while paying insufficient regard to the cultural frameworks of the lawmakers of the various jurisdictions studied. ${ }^{75}$ Perhaps even more damaging is that the ius gentium theory marginalises justifiable critiques of the ethnocentricity of the comparatist.

\footnotetext{
${ }^{74}$ R Lesaffer, 'The Lighthouse of Law' (2012) 17 Tilburg LR 153, 154.

${ }^{75}$ V Grosswald Curran, 'Cultural Immersion, Difference and Categories in U.S. Comparative Law' (1998) 46 AJCL 43, 61.
} 
To respond to these critiques, it is critical to develop an approach that preserves the underlying usefulness of a ius gentium theory while adding more nuance to its description. Accordingly, we can reconceptualise the ius gentium, either by describing it as emerging but not current reality, or by reframing it as a system of converging methodologies but not substantive norms. 